\title{
HISTORICAL APPROACH OF CONTEMPORARY UNDERSTANDING OF SCHOOL IN GLOBALIZATION ${ }^{2}$
}

ABSTRACT. Intercultural education respects and promotes diversity in all areas of human life. This phenomenon indicates that people naturally and spontaneously develop different lifestyles, different customs and worldviews. These differences need to be considered as a wealth of life. When we talk about education, and school as a narrow concept, in which the differences are usually promoted, we have a vision of a community that provides equal opportunities, opposes injustice and discrimination, and strives for the values which equality is being built on. Especially, this phenomenon is being pointed out in our conditions, when we are still adapting to the reforms of globalization.

In the Contemporary World, promoting the democracy becomes a key goal of education, as well as the whole society. Therefore, in the education system it should be taken into account the multicultural character of the society that tends to actively contribute to a peaceful coexistence and positive interaction between different cultural groups.

\section{jasnaparlic@yahoo.com}

2 The paper is based on research conducted as part of Project III 47023 "Kosovo and Metohija between national identity and European integration", funded by the Ministry of Education and Science of the Republic of Serbia.

This paper was submitted on 9 July 2015 and accepted for publication at meeting of the Editorial Board held on 8 October 2015. 
Traditionally, in this sense, there are two approaches in education: multicultural education that strives to provide the acceptance and tolerance of other cultures through learning about them. On the other side, we have the intercultural education that aims to overcome the passive coexistence and achieve developed and sustainable way of living together in a multicultural society. This is achieved through the construcive process of understanding, mutual respect and dialogue among groups of different cultures, then, ensuring equal opportunities and combating discrimination.

KEY WORDS: Interculturality, Globalization, understanding, democracy, school, multiculturalism.

Intercultural education in the era of globalization, primarily, aims to promote and develop a better understanding of culture in the contemporary society, communication among people belonging to different cultures. The focus of this issue is in a more flexible attitude towards cultural diversity in the society, therefore, it implies a greater willingness of people to actively engage in social interactions with people of different cultural backgrounds, as well as recognizing the fundamental characteristics of human nature as something common. It is also a process that requires us to know ourselves and our own culture as a first step toward an effort to know and understand other people and their cultures.

This process is full of challenges and includes work on the deeprooted beliefs about what is positive and what is negative, as well as full re-evaluation of their own world views in relation to their own lives of individuals. Intercultural learning is a challenge for personal identity and can become a way of enriching one's identity. The intercultural learning is a learning process of existence in the community full of diversity, and thus represents a starting point of developing common life intertwined with peace.

\section{DEFINING CULTURE}

Under the concept of culture, forms of human expression related to spiritual, intellectual, mental and symbolic expression are usually involved. More broadly, these include the natural and social sciences, philosophy, religion and all kinds of arts and narrow understanding of the concept implies practical implementation of cultural creativity. We should also distinguish the double meaning 
of this term. In one instance, it is possible to observe culture through customs of one community value system, through role models and ideals, etc. On the other hand, there are specific properties of individual behaviour and way of treatment (refinement, self-control, prudence, etc.) However, the concept of culture has contraconcepts, namely, when it comes to material aspects of social life (daily survival, economy, interests, etc.), as opposed to other cultures, and as a contrast in the form of coarseness, savagery, crudity and like. (Suzić, 2006, p. 7-29)

The term culture in the modern sense appeared in the second half of the 18th century, although the "cultural content" existed since the developing societies, and it is related to the close secularization, dominant worldview, and a man in it. As a comprehensive and itself, a sufficient whole, which today represents the concept of culture, could be identified only when it is seen as a part of the modern historical process, and also as a result of history.

The concept of culture occurs only in Western civilization. While other civilizational circles, albeit with certain cultural facilities, did not need to deal with it.

From the most general perspective, culture is the final step of human evolution; in terms of improving the security and continuity of life, at least a million years old. It depends on the ability to create symbols, and only a man is endowed with it.

\section{CULTURAL RELATIONS AMONG ETHNIC COMMUNITIES AND TOLERANCE AMONG THEM}

Education in the framework of cultural differences has the task to affirm the right to differentiate between people, but not discrimination because of the given differences. This phenomenon leads us to the acceptance of others as different, but also similar ones, with the difference being taken as an advantage or wealth, not as a weakness, as it often happens. Mutually distinct groups of people can cooperate with each other better in everyday life, if they know each other better; they can realize and understand each other, if they unite and help tolerantly. Nevertheless, education has the key role, then teaching and school as a narrower category.

The implementation of the idea of intercultural understanding at the time of globalization, especially in the ethical colourful com- 
munities, implies the realization of the basic tasks to forever banish prejudices and fears that are imposed upon us during the distant and recent past in the belief that all people are equal and equally worthy or that all have equal rights.

The love towards your country, customs, culture, is the starting point for the acceptance and tolerance of different traditions and cultures.

Therefore, in order to implement interculturalism in education, primarily, it is necessary to train those who work in education and upbringing of young people, educators and teachers.

As a general category, culture and language are mutually implied, because there is neither culture without a language expression, nor language without cultural content; at the same time, language is a means of expressing culture as well as its formative principle. On one level, "individual cultures and languages (which are difficult to separate and count) simple correlation is possible, but not necessary, because one culture may be exercised in several languages, one language can be a carrier of several cultures. Finally, there is a fine network of relationships on the verge of specific subcultures and related linguistic varieties." (Bugarski, 2005 , p. 45.) Regarding the national communities in Serbia and their culture in the first place is to cultivate language (Krstanović, 2009 , p. 35.) through the school system, media, and official use in areas with a higher concentration of ethnic minorities. Their culture and tradition in the wider sense, cultivate ethnic communities mainly through amateur artist troupes, such as the Hungarian community, for example, the only national community that has professional cultural institutions, as theatre "Ujvideki shinhaz" in Novi Sad and the theatre "Kostolanyi Deze“ in Subotica.

However, judging by previous experiences, we have learned about the need for expanding the socialization role of schools and deepening the relationship between school and society. It turned out that protection of Human Rights depends on the importance that society attaches to human rights and tolerance. The age of globalization imposes on us the need of a clear expression of tolerance at all levels of behavior throughout society and respect for human rights in everyday life. All these can lead to the creation of conditions for a broad socialization of these values. One option for achieving this task is provided within the intercultural concept that makes it suitable for education to disseminate the spirit of tolerance (and human rights) in a modern pluralistic societies. 
The relationship of education and tolerance in the actual moment of globalization reforms certainly includes variations such as education for tolerance, tolerance in education, education in tolerance. Although, each model of different meanings, experiences and analysis show how important is every aspect of their relationship.

According to the pedagogical theory, education in the narrow sense is a process of developing the sensitive part of the personality, as well as shaping the attitudes and composition of values, and in a broader sense, it is an integral part of education.

At the time of religious wars, for example, it was necessary to work on the acceptance of communal life with members of other faiths. Later this demand has spread to the acceptance of living together with other ethnic and racial groups. Otherwise, under the tolerance it is generally refered to the moral virtue of an individual (which actually represents the horizontal dimension of relations between members of a society) and to the political virtue of the liberal state (which is the vertical dimension of the relationship between a state and an individual).

Tolerance can be defined as the behavior which allows others freedom of expression; everyone can live in accordance with their principles, although they differ from our own.

Educational system organized by the state and functioning of this system depend on mutual connectivity of the parts of the system. This system consists of not only institutional form of education, but a series of related structures that enable a given operation.

\section{TOLERANCE AND SOCIALIZATION IN GLOBALIZATION}

The establishment of national states is formed by the nation and with it the demand for cultural or national homogeneity. The state has this requirement fulfilled by introducing compulsory, mass public education. The main objective of educational programs was the socialization of loyal citizens within a common national culture and raising awareness of a common past (which prevented the emphasis of the internal differences). Although diversities were 
suppressed, they regularly have an impact on inter-ethnic relations.

Within educational composition or structure, school has a special role in the transferring or strengthening prejudices on which tolerance is being built. Schools and the media, education and information are two important sources of prejudice that have a significant role in determining the perception of other people and those - whether they are individuals or groups-who are different.

Many educational compositions are trapped within their own monoculturalism (and ethnocentrism), and societies become more diverse, or increasingly develop awareness about the diversity and interdependence. At the time of globalization, there is a sudden need for open-mindedness, respect for other cultures and awareness of the shared values that are essential for democratic framework and implementation of social and human rights. That is why it is necessary to avoid ethnocentrism and nationalism in the curriculum and in the composition of the values that are passed on to new generations.

Otherwise, the general crisis of identity for its consequence has the emergence of "yes men (who) tend to force the identities of communities based on ethnic group, nation, religion or territory, and which obscures the fundamental rights of individuals, freedom of conscience, prudence and an universal appeal". (Perotti, 1995, p. 13.) Thus, "it is often on the part of the phenomenon that Freud called the narcissism of small differences which acts in opposite direction of emphasizing cultural diversity at the expense of the similarity of the neighboring cultures " (Stojković, 2002, p.15.) or nurtures the principle of diversity for the sake of diversity itself. As most critics considered that one of the greatest weaknesses of the policy of multiculturalism is to emphasize the difference. And in education, the concept of multicultural education is often focused on the differences, while the concept of interculturalizm and intercultural education aimed at communication and finding new synthesis. Multicultural education is more focused on the specific needs of one category, and intercultural, for example, on the customizing the system to new requirements set by the existing multiculturalism context of society.

While concept of intercultural in the new circumstances starts from intercultural diversity and expands on the complementarity of the universal and the singular, dynamic and flexible dialogue must be open,. We could conclude that, while the multicultural 
education is the product of American society, the concept of intercultural education is European. Antonio Periotti lists several guidelines which occurred in the European Council for Cultural Cooperation, aiming to correct certain errors. Namely, the multicultural societies in Europe can not be defined neither as the coexistence of diversity, nor in the form of a dichotomy. If multiculturalism is defined as coexistence or as a mosaic in which different groups live side by side, we will have a static version of culture and what is needed to be taken into account is the interaction between individuals, communities and groups. Further, no dichotomy majority / minorities or indigenous /immigrants is fruitful, but should focus on the study of the elements which unit them, or link them. Lastly, a European multicultural society can not be equated with the concept of melting pot or smelting plant Peoples (melting pot) because it is considered that each individual remains attached to its original culture, no matter how many elements from other cultures accept it. One can not predict the difference between multicultural societies such as the USA, Canada or Australia, on one side, and multiculturalism in Europe on the other. These countries are "strictly speaking, countries of immigrants, and they and their children are engaged in nation-building" (Perotti, 1995, p. 55), while immigrants in European countries, although they contributed to the culture and economy, did not participate in the process of nation-building. Finally, as Perotti stated (Пероти), the Council for Cultural Cooperation of the Council of Europe determines the "multicultural society as a political society that assumes adopting common rules of communication. This assumes one and more official languages, a common legal system, social democratic rule, respect for human rights and freedom of the individual against the pressure of the community. (Perotti, 1995, p. 55)

Intercultural education in an age of globalization is aimed at raising awareness of the cultural pluralism of modern societies. It shall contribute to the fulfillment of the following objectives:

- Overcoming social disparities and inequalities in education ,

- Developing respect and tolerance for cultural differences among men ,

- Assisting pupils/students to acquire basic knowledge about interethnic relations and sensations underlying the different cultures, rather than based learning the emotional and class assumptions. (Petrović, 2002, p. 43). 
Therefore, intercultural education does not aim only to teach about different cultures. Informative knowledge about diversity is essential. It is only the basis which moves and continues to step further in revealing the relations. Establishing relations among carriers of different cultures is the essence of intercultural pedagogical activities. Knowledge must be supplemented by experience which involves trial and error in establishing contacts in intercultural personal circumstances.. The Italian ethnologist and political anthropologists Christian Giordano (Кристијан Ђордано) explains that the specificity of misunderstandings arising from cultural contacts is not viewed as a kind of pathological conditions, or as a dysfunctional phenomena, but he determines them as the basis of intercultural communication. This process is defined as a contact, interactive situation in which by rule misunderstandings occur, because two cultures that are in contact do not share the same " Subjectively perceived meaning", according to Weber's terminology. (Giordano, 2001, p. 14)

In this context, interculturalism is a personal and cultural maturation of the individual through the opportunity to compare their own culture with the others. Intercultural education aims to teach students communication and prepare them for conflict situations in which relationships are not and can not be automatic. In this way, it allows orientation in relationships with other people, expanding the range of its own references and experience of different cultural personal characteristics in the environment. (Ninčević, 2010, p. 53-61) In order to develop these relations one must be bear in mind that identities are not given in advance but that they are built, upgraded and improved; that is a kind of transmission. The identity is not imposed from the outside and is not a restrictive category.

In the debate on intercultural communication and intercultural education the concept of intercultural competence can not be omitted. Majkl Bajram (Мајкл Бајрам) also deals with this issue and he defines intercultural competence as a skill of real interaction with people coming from different cultures. Thus, interculturally competent person is the one who can recognizes a relationship between two or more different cultures. This person has the capacity of mediation and interpretation, as well as critical and analytical understanding of his own culture and cultures of the others. (Бучо/Buсо, 2010, p. 53-61) 
Dimensions of intercultural competence are: cognitive, emotional or behavioral. Therefore, it is manifested through certain cognitive activities such as empathy, motivation to adapt, as well as through communication and flexible behavior towards a different worldview or vision of reality. This implies that the values, beliefs and behavior are characteristics of their culture and do not assume it as the only possible and naturally correct, as assumed by cultural monistics. These same elements are seen from another perspective, or nurtured in a decentralized worldview.

Perh (Парех) also deals with such relations between cultures. He believes that if we want to evaluate a culture from the outside, we must know and understand the inside, and we should not expect from other cultures to meet our own standards of right and wrong. However, the concept of cultural relativism, which means that every culture is a self-sufficient unit with its own particular values and that they are not mutually comparable, according to Pareha, $a$ is an incoherent doctrine. Therefore, comparison of cultures is possible if there are some minimum universal values. However, "although we can not compare the whole cultures, we can compare their specific aspects. So we can argue that the literature of one culture is richer or that its spirituality is deeper “. (Mesić, 2006, p. 103) When it comes to respecting the different cultures in a time of globalization changes, there are two dimensions. The first implies that each culture covers one particular community and that members of the community have the same right as everyone else to nurture their own culture, and in this sense deserve respect. The second dimension relates to the content and character of culture.

Intercultural approach in education in the era of globalization is not a new subject, but a new methodology that attempts to search for the truth, encompassing the sociological, psychological, historical, political, cultural and economic factors in each school subject. Some authors believe that the teaching of history provides the most space for the implementation of interculturalism. Studies of school books of history have shown presence of a high degree of ethnocentrism. The material in textbooks is often mono-cultural, which includes glorification of our own and contest against other cultures, which moves away from the Eurocentric vision of the world; the effect is that the students were not even given the opportunity to become familiar with the cultural achievements in, for example, Indian or Arab culture. The matter with the history, philosophy, literature or art is that it does not take into account the 
creative achievements of other civilizations. Perotti (Пероти) criticized this selective memory in Europeans and believes that they must urgently remember plurality of its cultures. He also cites insufficient attention to the phenomenon of religion. These gaps make communication more difficult for citizens who are in daily contact with Christianity, Islam, or atheism. If there is no knowledge about it, it is hard to achieve dialogue and understanding. By adopting the position that such starting point needs a good awareness of different cultures, it is not possible to bypass religious elements which have had or still have an important role in the establishment of a system of values of given cultures. Otherwise, education in religious terms of pluralism is an integral part of intercultural education and includes two aspects: the individual's relationship to religion and relationship among people belonging to different religions. The phenomenon of religion should be interpreted from the standpoint of history, sociology and geography and put it into the context of modern globalized society. Also, in the study of different religious traditions should be represented a comparative approach.

Another case, which should be a move from traditional-intercultural globalist understanding, is the geography. This subject particularly deals with the facts that are particularly important for experience of multiculturalism, where we include territoriality, identity, and diversity. The teaching of geography should include learning of specific identities, as well as common problems and goals in the society. Particular attention should be paid to the phenomenon of migration which represents one of the basic conditions of multiculturalism. Regarding the school atlases, it is advisable to use a variety of thematic maps that spatially show demographic data on the mechanical movement of population, the use of language, religion or widespread environmental problems.

Intercultural approach is easily accomplished in the arts. The one who knows the art of a particular culture is largely closer to that culture. The art is a means of communication and can be used in the presentation and acceptance of cultural diversity. For example, knowledge of music of a particular culture can motivate people to start learning a foreign language, and music can be used as a method that will help them to master the language already learned.

Also, in the teaching of foreign languages knowledge of other cultures is considered very important. Objectives of teaching cultural intercommunication in a foreign language are, in addition to 
acquiring knowledge and developing skills for the realization of interaction with speakers of other languages, on an equal basis, which equally recognizes their own identity, and the identity of the interlocutors. Theoretical theses/settings completely substantiated by the results of the research as well as teaching practice itself confirm that students are not only sufficiently knowledgable of the language but also enabled to use the language in a socially and culturally appropriate manner. Although, the most subjects are suitable for application of the intercultural concept and it is shown how necessary and useful it is, there is one item/subject that can be set aside. Only in a civic education development of the intercultural concept is an aim in itself. This item is focused on education for a democratic society which includes raising awareness of pluralism of social reality and the possibilities for life in a multicultural climate. Therefore, civic education could help the youth to develop better and more realistic understanding of today's world, to become active participants in the decision-making process, responsible and informed citizens in accordance with the basic principles of democracy and an open and dynamic civil society. (Budic, 2009, p. 33) The basis of civic education as a school item is learning about human rights.

It is necessary to point out another gap in civic education, and it refers to the fact that school textbooks do not mention the Roma community at all. If the textbooks do not transmit knowledge and do not share information about a particular cultural community, it is not expected that this culture will be able to be included in the society and also to establish a relationship with other cultures. Dealing with the Roma community presumes consideration of its specific features, that it is a culture without a home country, or that it is one of the contemporary cultures of everyday life. According to research results cited by some authors (Пероти), the prejudices towards Roma are still strongly present in our society and also their inclusion into society is difficult. In European history this is one of the most jeopardized minorities. Roma residents are still on the margins of the society and ensuring the conditions for their education is one of the main tasks of the European education, which should result in no rejection nor forced assimilation as is often the case. It is not rare either for Roma children to be placed in schools for children with disabilities. In some countries there is a social policy aimed at solving this problem but they still have not yielded significant results. 
Intercultural concept should not be limited to the formal education. As education is no longer perceived as a closed sector, but as a process that is a part of everyday life and which is implemented both at school and outside, informal education is increasingly gaining in importance, in this regard, intercultural approach should become an integral part of the continuing education.

The main purpose of the educational system is to enable individuals to grow into an independent and responsible person. " today's education requires that we create a common understanding for others, the ability to accept change and awareness of possibilities of mankind. "(Giddens, 1996, p. 74) Durkheim believes that the pedagogical ideal of an era is the indicator of the state of the society in the respective epoch. (Durkheim, 2001, p. 155) In order to realize the intercultural concept, it is needed to reform a traditional form of education, not only to introduce newspapers in the curricula, but also to change the organization of teaching. Frontal way of material presentation should be abandoned and various forms and methods forcing active participation and teamwork should be introduced, which strengthen group cohesion.

The role of teachers in modern education systems undergoes significant changes and modernization. There has been a change in the pedagogical paradigm which requires developing research competences, overcoming the dichotomy theory-practice and the fostering of innovative and interactive approach. The teachers are expected to continually develop, train, observe the latest trends, be well informed about social events, achieve media literacy to high level as well as great flexibility and willingness to adapt to changes.

A teacher who possesses these characteristics is able to develop intercultural competence and skills to implement the policy of intercultural education always keeping in mind the richness of diverse cultures and the possibility of their interaction. What is important is to emphasize that the constant professional training should involve teachers in the entire education system. Training for intercultural approach is not only intended for teachers who are specialized to teach the children of immigrants, or to educate children of ethnic minorities in their mother tongue. "there are special teaching methods appropriate to different types of teaching and various objectives. But intercultural education goes further in everyday situations, that is why all teachers must apply the intercultural approach" (Perotti, 1995, p. 101) and is designed for all students. 
However, despite major efforts to reform, the crisis of education is still present. Despite the abundance of available information, the pupils were still insufficiently informed, their school achievements are weak, and the reputation of teachers is reduced or disappeared altogether. It should, therefore, be improved by all costs: to bring more participation and pedagogical research (Lipovecki, 1987, p. 46) but the paradox is that, as more schools follow the wishes of students and making them more directed to actively participate in the educational process, it is their motivation that is weaker. As rights are more expanded, there is less respect and responsibility that should go hand in hand with those rights. The higher hopes of education is a force which can contribute to the progressive transformation of society, it is proving to be a means to reproduce the existing social structure. In the work toward the equal educational opportunities for all, it is shown that the inequality remains entrenched. Reasons for that are largely due the the fact that the problems are solved partially, not examined as a whole. Therefore, it is necessary to continue reforming the education and finding new paradigms to solve these problems, a concept of interculturality certainly must be included.

\section{INTERCULTURALISM AND GLOBALIZATION AT SCHOOL}

The idea of interculturalism emerged as an understanding of the effects of demographic growth of foreign communities in Europe, in multiethnic and multicultural characteristics of European societies, and above all and in particular, the function of education and schools. It is an expression of the failure of different projects of integrating societies and nations, and the attempt that instead of general assimilation on one side and antagonism, stereotypes and prejudices, on the other hand, to establish a valid dialog “. (Djurišić - Bojanović, 2003, p.137-143)

While multiculturalism means the existence of multiple cultures in the same space, interculturalism emphasizes the relationship between cultures and the necessity of interaction, exchange, collection of dynamic flows that characterize the interaction between individuals of different cultural backgrounds. Therefore, the relation between cultures and necessity of interaction is emphasized. 
Interculturalism implies not only the presence, common life, mix different cultural forms, but the possibility of comparing ideas, opinions, encouraging reflection on the differences of ethnic, religious, cognitive, sexual or any other nature. Interculturalism also means providing opportunities for coping, communication, exchange of values and mutual understanding of the diversity.

Interculturalism means also finding the valid conditions and incentives for the development of diversity. It also means influencing upon development of self-concept, creating and deepening of knowledge about oneself. Thus, it is an approach, the idea, the dynamic phenomenon of cultural interaction and cultural dynamism. (Kostović and Ćermanov, 2009, p. 3). Interculturalism is considered one of the guiding principles in education.

In addition, interculturalism as innovative approach in globalist school strengthens the development of a common school culture based on knowing of and respecting the differences that are present in the school. The objectives of intercultural education are a direct confrontation with ethnocentrism, racism, stereotypes, prejudice, inequality and discrimination in schools and society. Intercultural education in our school system creates the openness towards other cultures, cultural and intercultural knowledge, including cross-cultural experiences and, above all, the uniqueness and value of each culture and its contribution to the situation within the globalist reform.

Thus dimensioning of school by taking into account the intercultural approach, its confirmation has in many documents of the Council of Europe, Council for Cultural Co-operation, and UNESCO. Also, a significant number of international experts in the consideration of the function of the school in a multicultural society came to similar observations.

\section{TEACHER COMPETENCES AND INTERCULTURALISM}

Besides the effects on interculturalism macropedagogic school plan, a significant implication of this innovative approach can be seen in the area of roles, functions and competencies as important variables in the school context. Issues of teacher's position, his/her functions, roles and competences at school are as old as the school itself. 
Profiling of teachers is derived from the development of social relations that affect the school as a macro-society. Considering changes of the social context, changes in the school context are inevitable, including changes in the functions and competencies of teachers. They become complex, multi-purpose and susceptible to quantitative and qualitative changes (Stojakov, 1999, pp. 7-24)

Interculturalism as a new dimension in education also affects the functions and competences of teachers at school. One of the most effective ways by which schools can adequately react to changing circumstances and diversity of its students is the professional development of teachers. Programs for professional training can be differently dimensioned in relation to the content, duration, target group, and so on. During professional development teachers need to be familiar with interculturalism, to primarily bear in mind the richness of different cultures, their interaction and development. Professional development programs can be realized through courses, training, seminars in the different institutions of education, through observation of classes of other teachers, through team work in designing curricula, modules, through study visits, exchange of teachers, etc.

\section{THE CURRENT DEGREE OF METHODOLOGICAL RESEARCH INTO THE INTERDEPENDENCE OF CULTURE AND EDUCATION}

The starting point for researching of intercultural approach to ethnic diversity and identity is theoretically and empirically founded knowledge about the need for unmasking and deconstruction of "false multiculturalism" that are oriented only towards creating parallel homogeneous cultural attitudes. Identification procedures and ethnic relations in Serbia are in the center of the research, which due to its past within multiethnic and multinational states, has a paradigmatic potential for the study of inter-ethnic relations and their regulation, especially in the processes of supranational associations. Special attention was paid to the following issues: the institutionalization of the rights to cultural and ethnic diversity in Serbia, identification forms and impact of social change on the minority - majority ethnic relations, and relations among and within minority communities in Serbia. These problems will be investi- 
gated comparatively firstly in a wider European context, with particular reference to other countries, in cooperation with local researchers.

The existing situation in the education system regarding interculturalism was analyzed by several international and national organizations (OECD and UNICEF - Comprehensive reports from 2001 and 2003, various reports on specific aspects of Education by UNESCO, the European University Association (EUA) institutes and organizations dealing with education in Serbia, analysis of results of international tests such as PISA, TIMSS, etc.) and local institutions (eg. within the document of the Ministry of Education and Sports 2001-2003" Quality Education for Everyone ").Some important aspects of reform process were being started but also stopped in the meantime, such as, for example, curriculum reform based on learning outcomes. The process of higher education reforms proves to be lacking understanding of the objectives on which it is based. The results of some researches (eg. achievements of students at various levels in primary schools) are not available to the public or are declared irrelevant.

It is difficult to find valid data in Serbia, and therefore it is difficult to evaluate success of different levels of formal education which are based on world (OECD, World Bank) and European (Council of Europe) indicators which are mostly used in the European Union to evaluate the success of certain aspects of the educational system at all levels of scientific and research activities, professional education and training.

In essence, the democratization should provide access to quality education; participation of all stakeholders in the process of change, the real participation of all children in the regular education system; conditions for exercising of continuing education, greater flexibility of school curricula for the influence of local communities, such as: interculturalism of school programs in multicultural environments; development of democratic relations and respect for all stakeholders in the educational process as well as the values that are transmitted through classes and extracurricular activities.

In this sense, the school except educational, has a significant socialization, educational and cultural function; it also represents an indispensable and very important factor of the overall personality development of young people and their self-realization. 
The objectives, curricula, organization of work, educational activities and relationships in school are changing in line with the major changes in the scientific, technical and technological, economic, political and cultural development of society, and the need for modernization of their own educational activities.

At the beginning of ??I century, our schools are still, to a greater or lesser extent, at a disadvantage, phenomena and concepts that characterize the traditional school are applicable to ours: Marginalisation the position of students as subjects and neglecting their psychosocial needs: insufficient connection of school with life and social environment, the overwhelming focus on the acquisition of knowledge rather than on the overall personality development; insufficiently democratized relationships in school, especially from among students and teachers; domination of verbalist methods, obsolete and non-functional educational content; insufficiently developed comprehensive system of programming, monitoring, and evaluation of educational work, etc.

Different global approach assumes qualitative changes of traditional teaching strategies and creating socio-emotional climate in the development of the individual who is open minded for diversity, multiplicity and complexity, as in the encounter with new information, and communication with other people. Just communication with others, through development group dynamics, group work in the classroom and cooperative teaching and learning leads to such interpersonal relationships in which differences are accepted as a principle of integration.

In intercultural understanding, education should help to raise awareness of its own cultural identity, strengthen the ability of efficient perception of reality, accept oneself (development of selfconcept), and thus accept others. The development of self-respect and self-confidence, as well as the universal tasks of education, lead to increased openness, flexibility, specialties in understanding and vision of the world around us. It is a condition for intercultural competence in different contexts.

Mentioned differences between national cultures influence not only the structures and processes in organizations and institutions, but also the model of economic development, as well as the overall social relations. Cultural programming begins in the environment in which children grow - in the family. It continues at school and what goes on there can only be understood if we know what happens before and after school. This process is being continued in the 
workplace. Behavior of employees is an extension of habits learned in school and family. Managerial behavior is a continuation of school and family experiences, but is influenced by the behavior of the subordinates. Policy and relations between citizens and government are an extension of relations in the family, at school, at work, and it all together affects other areas of life. Religious beliefs, secular ideologies and scientific theories are "the extensions" of mental software that is expressed in the family, at school, at work, in the political sphere and they reinforce prevailing patterns of thinking, feeling, and acting in other areas.

Because of its complexity and contradictions in contemporary multiculturalist society, many questions remain open. To understand social diversity which is imprinted in the social reality does not mean finding a general validity of a simple formula. Parallel processes of globalization and multiculturalism exacerbated the crisis of modernity, which is primarily crisis of culture, which in turn is primarily a crisis of identity. The consequences of these phenomena are the tensions in the relations between members of different groups. Tensions before the cultural and educational policies put additional pressure.

Multicultural education occurs as a reaction to the assimilating model which was implemented within the framework of monocultural education. Monocultural education was an ethnocentric, generally preferring one culture and all people housed in the same homogeneous mold in the expectation that they will adapt and the differences will disappear. Multicultural education criticizes and overcomes this model as a part of developing sensitivity to cultural diversity. It calls for recognition of the special rights of minority groups which are the same.. It also advocates for change in curricula, which would be inclusive in terms of being respectful of heterogeneous group and informed about their specific characteristics, creative achievements, history, and contemporary lifestyle.

However, there are also those supporters of multiculturalism who are committed to specific programs and special epistemology for each group, which contributes to segregation and strengthening of new ethnocentrism. This criticisms indicates that multicultural education usually refers to the immobility and the excessive emphasis of cultural differences.

The concept of intercultural education is a product of the European social theory and it attempts a response to these criticisms 
through new, dynamic dimension. Intercultural education aims not only informed about diversity but to bring these differences in the relationship. Awareness of history, accomplishments and way of life of different groups is the starting point, but the essence of the intrecultural education is the next step - the establishment of an interaction and communication between members of different cultures and discovering their similarities and the elements that connect them. Knowledge of the differences builds on the experience of diversity through the search for similarities. This access is not segregational because it is not directed only at certain groups and does not care for the needs of only certain categories, but encompasses all. All group members are expected to engage in a dialogue in a way that will allow their cultural uniqueness to be preserved, and that will open the possibility for finding a new cultural synthesis.

Such intercultural communication can lead to misunderstandings and conflicts, where the dialogue does not take place automatically and where it is difficult to define some universal mechanisms of dispute settlement..

However, with the development of intercultural competences as the actual interaction skills and critical and analytical thinking about onećs own culture and the culture of another, this would still result in dynamic aspect of better understanding and cooperation.

LITERATURE Башић, Г. (2006). Локална gемокрайија и међунациинални ояноси. Београд: Институт за филозофију и друштвену теорију Београд.

Бугарски, Р. (2005). Кулӣура и језик. Београд: Библиотека ХХ век.

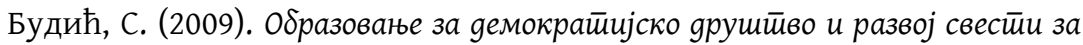

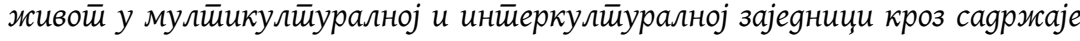
ірађанскої васӣuйања. Нови Сад: Филозофски факултет.

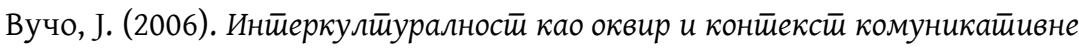

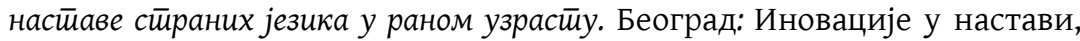
Учитељски факултет.

Диркем, Е. (1981). Васӣuӣaњe и социиолоїија. Београд: Завод за уџбенике и наставна средства.

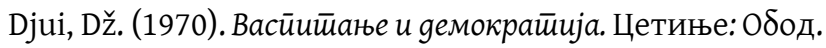

Буришић-Бојановић, М. (2003). „Мултикултуралност и мултиперспективност у образовању”. У: Ј. Шефер, С. Максић и С. Јоксимовић (ур.), Ува-

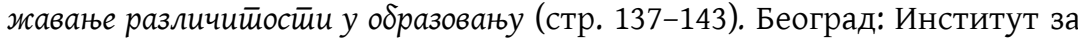
педагошка истраживања. 


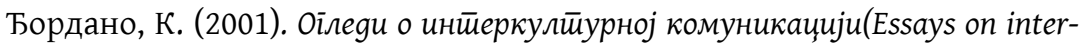
cultural communication). Београд/Belgrade: Библиотека XX век./Library XX century.

Костовић, С. и Ћерманов, J. (2009). Изазови иниееркулӣурализма и школа, Нови Сад: Универзитет у Новом Саду.

Крстановић, С. (2009). „Интеркултуралност и културна политика”. У 3.

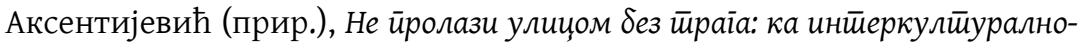
сйu (стр. 33-44). Београд: Група 484.

Липовецки, Ж. (1987). Доба йразнине (The age of gaps), Нови Сад: Књижевна заједница Новог Сада.

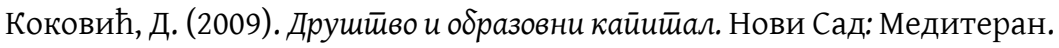

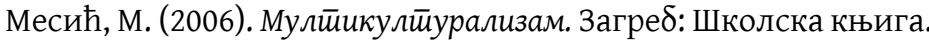

Mil, J.S. (1995). Izabrani politicki spisi, sv. 1. Zagreb: Informator.

Ненадић, М. (1997). Нови gух образовања. Београд: Просвета.

Perotti, A. (1995). Pledoaje sa interkulturalni odgoj I obrazovanje (A plea for intercultural education). Zagreb: Educa.

Петровић, А. и Јањетовић, Д. (2002). Инӣеркулӣурално образовање у нашим школама. Изазови gемокрайије и школа. Београд: Институт за педагошка истраживања.

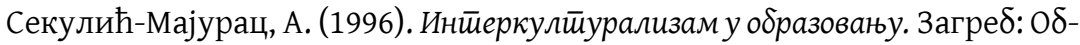
новљени живот.

Стојаков, С.(1999). „Мултикултуралност као обележје квалитета образо-

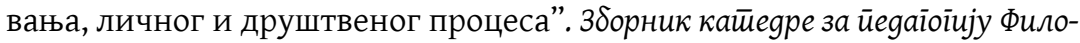

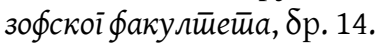

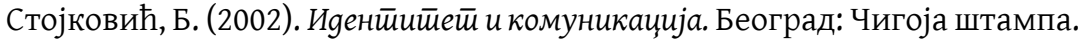
Сузић, Н. ( 2001). Соичолоіија образовања. Сарајево: Завод за уџбенике и наставна средства Републике Српске. 
ЈАСНА Љ. ПАРЛИЋ БОЖОВИЋ

УНИВЕРЗИТЕТ У ПРИШТИНИ С ПРИВРЕМЕНИМ СЕДИШТЕМ

У КОСОВСКОЈ МИТРОВИЦИ, ФИЛОЗОФСКИ ФАКУЛТЕТ

РЕЗИМЕ

ИСТОРИЈСКИ ПРИСТУП САВРЕМЕНИМ СХВАТАҢИМА ШКОЛЕ

У ГЛОБАЛИЗАЦИЈИ

3бог његове комплексности и контрадикција у савременим мултикултуралним друштвима, многа питања остају отворена питања. Да ठисмо разумели друштвену разноликост која је писмено социјалну дисцрепанциит није могуће пронаћи једноставан и свеприсутну формулу. У паралелни процеси глобализације и мултикултурализма погоршало кризу савремености, што је пре свега криза културе, што заузврат је, пре свега, мултикултурно образовање је био одговор на модел асимилације која је примењена на монокултуралног образовања. Монокултурна о образовању био етноцентричан, углавном пожељан у истом контексту, хомогена калуп у очекивању да ће бити прилагођена разликама нестане током времена. Мултикултурно образовање и критичко иза овог модела по развоју осетљивост на цоол.Ит залаже за признавање и остваривање посебних права за мањинске групе у којима исти је одбијен. Такође је позива на промене наставног плана и програма који ће бити инклузивни, у смислу да поштовани хетерогенос.Ховевер, постоје и оне присталице мултикултурализма, залагање за посебну програмде и посебним епистемологије за сваку групу која доприноси сегрегације и јачања нових облика етхноцентрисм.Цритицс указују на то да мултикултурално образовање се најчешће односе на непокретности и прекомерне истуреност културног дифференцес.Тхе концепта интеркултуралног образовања је производ европске друштвене теорије и покушати да одговори на ове критике кроз нову, динамичну димензију. Интеркултурално образовање има за циљ не само за информисање о различитости, али да се те разлике у ставовима. Свест о историји, достигнућима и начином живота различитих група је полазна тачка, али је суштина интеркултуралног образовања у сљедећем интеракцију и комуникацију између различитих култура и откривањем њихових сличности, да су елементи повезани. Знање о различитости заснива на искуству другачије. Овај приступ није одвојен пут, јер није усмерена само на одређене групе, а не водећи рачуна о потребама одређене категорије вец све покрива. Припадници 
свих група, очекује се да омогуће својим културни идентитет да се очува, и да ће отворити могућност за проналажење новог културног синтезу. Таква интеркултурна комуникација може довести до неспоразума и сукоба у којима дијалог не одвијају аутоматски, и где је тешко дефинисати универзални механизам решавања спора јер је културно условљен. Међутим, са развојем компетенција, као вештину интеркултуралнде стварних интеракције способности и критички и аналитички размишљања своју културу и друге културе, то ће и даље бити динамички аспект резултатима бољем разумијевању и сарадњи.

Кључне речи: Интеркултуралност, мултикултуралност, савремена школа, глобализација. 